\title{
THE RELATIONSHIP BETWEEN MULTICULTURAL COMPETENCIES AND INTERCULTURAL CONTACT: MULTICULTURAL PERSONALITY AND CULTURAL INTELLIGENCE
}

\author{
A RELAÇÃO ENTRE AS COMPETÊNCIAS MULTICULTURAIS \\ E CONTACTO INTERCULTURAL: PERSONALIDADE \\ MULTICULTURAL E INTELIGÊNCIA CULTURAL \\ LA RELACIÓN ENTRE LAS COMPETENCIAS MULTICULTURALES \\ $\Upsilon$ EL CONTACTO INTERCULTURAL: PERSONALIDAD \\ MULTICULTURAL E INTELIGENCIA CULTURAL
}

\author{
Cátia Sousa ${ }^{1}$, Gabriela Gonçalves ${ }^{1}$, Joana Santos ${ }^{1}$ \\ e Alejandro Orgambídez-Ramos ${ }^{1}$ \\ ${ }^{1}$ Universidade do Algarve, Faro/Faro, Portugal
}

\begin{abstract}
The everyday contact with people from different nationalities is nowadays a reality. Cultural Intelligence and Multicultural Personality are individual competencies that are becoming important to deal with this reality. In this study, with 313 Portuguese participants, of both genders, with different types of intercultural contact, our purpose is to observe the effect of the intercultural contact on cultural intelligence and multicultural personality levels. The results show that there is a significant relation between the cultural intelligence and multicultural personality levels and the type of contact with individuals from different nationalities. Both cultural intelligence and multicultural personality have strong implications for a work context that is more and more characterized by cultural diversity.

KEYWORDS: Cultural intelligence; Multicultural personality; Expatriates; Intercultural contact.
\end{abstract}

RESUMO: O contacto diário com pessoas de diferentes nacionalidades é hoje uma realidade. A inteligência cultural e a personalidade multicultural são competências individuais que têm se tornado de extrema importância para lidar com esta realidade. Neste estudo, com uma amostra de 313 portugueses de ambos os géneros, com diferentes tipos de contacto intercultural, o nosso objetivo é observar o efeito do contacto intercultural nos níveis de inteligência cultural e de personalidade multicultural. Os resultados mostram a existência de uma relação significativa entre a inteligência cultural e a personalidade multicultural e o contacto intercultural. Ambas as competências têm fortes implicações no contex to de trabalho, caracterizado, cada vez, mais pela diversidade cultural.

PALAVRAS-CHAVE: Inteligência cultural; Personalidade multicultural; Expatriados; Contacto intercultural.

RESUMEN: El contacto diario con personas de diferentes nacionalidades es un hecho cotidiano en la actualidad. La inteligencia cultural y la personalidad multicultural son habilidades individuales que se han vuelto extremadamente importantes para hacer frente a esta realidad. En este estudio, con una muestra de 313 participantes portugueses de ambos géneros, con diferentes tipos de contacto intercultural, nuestro objetivo es observar el efecto del contacto intercultural en los niveles de inteligencia cultural y personalidad multicultural. Los resultados mostraron que existe una relación significativa entre inteligencia cultural y personalidad multicultural y el contacto intercultural. Tanto la inteligencia cultural como la personalidad multicultural poseen una gran relevancia en el contexto laboral, cada vez más caracterizado por la diversidad cultural.

PALABRAS-CLAVE: Inteligencia cultural; Personalidad multicultural; Expatriados; Contacto intercultural. 


\section{Introduction}

Countries are becoming culturally diverse and demography is changing (William \& Johnson, 2011). Thus, everyday contact with people from different nationalities, races and cultures is a reality in social situations and organizations. The increase in immigration, expatriation and multicultural organizations make the daily interaction with individuals from different cultures inevitable (both citizens of host countries and those who are displaced), and working and interacting with people from different cultural backgrounds can be a complex process for individuals, since cultural barriers might originate misunderstandings and disturb cross-cultural interactions (Adler, 2002).

According to Tung (1993) communication is the basis of the process of mutual understanding in any cultural interaction. Moreover, since Allport's contact theory (1954), intergroup contact has been pointed as a way of reducing prejudice, improving intergroup social interactions (e.g., Cao \& Lin, 2017; Davies \& Aron, 2016; Pettigrew \& Tropp, 2006). Contact between groups, by providing positive experiences, enhances the perception of similarity between members of different groups, leading to the deconstruction of negative stereotypes (Allport, 1954). Particularly between minority and majority groups such as the host society and immigrants (e.g., Verkuyten \& Yogeeswaran, 2019). However, the ability to interact effectively in intercultural contexts, though vital in today's world business and societies, is not a skill that everybody possesses (Crowne, 2008). Cultural diversity has created new challenges for both society and the workplace, in particular the "acquisition of cultural competencies that enable a better understanding of the values, practices and social norms linked to new immigrant wave" (Malheiros, 2011, p. 11). In this context, cultural competences such as cultural intelligence and multicultural personality have emerged in the literature as an asset to deal with cultural diversity (e.g., Sousa, Gonçalves, \& Santos, 2019).

Cultural intelligence and multicultural personality are fundamental competencies for a successful intercultural interaction. Both allow to evaluate multicultural competencies and obtain useful information about the strategy, motivation, performance and effective adaptation in diverse cultural contexts. Empirical research has shown that intercultural adjustment is largely facilitated by cultural intelligence and the various dimensions of multicultural personality (Peltokorpi \& Froese, 2012). Various studies have suggested that high levels of multicultural personality are associated with social and psychological well-being, life satisfaction, adjustment facility, and intercultural assimilation (Ali, Van der Zee, \& Sanders, 2003; Mol, Van der Oudenhoven, \& Van der Zee, 2001; Van der Zee, Van Oudenhoven, \& Grijs, 2004). We believe that these competencies are relevant to the quality of social interactions between people of different cultures. Effective social interaction by the host country contributes to the good integration of foreigners, to social peace, to the well-being and satisfaction of individuals (e.g., Ghosn, Braithwaite, \& Chu, 2019). On the other hand, in organizational terms our results can contribute not only to define employee selection tools but also to outline strategies that promote contact with other cultures, allowing for the development of a better individual, team or organizational performance in multicultural environments.

Thus, considering that intercultural contact has positive effects on cross-cultural social interaction competencies, particularly on Cultural Intelligence and Multicultural Personality, this study aims to observe the effect of intercultural contact on the development of these competencies. 


\section{Cultural Intelligence (CQ)}

Cultural intelligence, motivated by the practical reality of globalization in the workplace (Earley \& Ang, 2003; Fang, Schei, \& Selart, 2018), is defined as a set of skills/ competencies that facilitate the adaptation to diverse cultural situations and allow the interpretation of unfamiliar situations and behaviours, as well as the identification of behaviours that are universal to all humankind. The concept is also perceived as the set of behaviours that are cultural and idiosyncratic of a special individual in a special situation (Van Dyne, Ang, \& Livermore, 2010). For Earley and Ang (2003), cultural intelligence is a multidimensional concept that comprises four dimensions: metacognitive, cognitive, motivational, and behavioural (e.g., Rockstuhl, \& Van Dyne, 2019). The metacognitive dimension is about the cultural consciousness and sensibility awareness during cross-cultural interactions. It is considered a crucial dimension, since it promotes an active thought about people and situations in different cultural settings. In addition, it promotes a critical thought about habits and beliefs, and allows an evaluation and revision of the mental maps, increasing the understanding capacity (Van Dyne, Ang, \& Koh, 2008; Lorenz, Ramsey, \& Richey, 2018), i.e., for those who get a loose connection with their own culture it will be easier to adopt the habits and customs of a strange culture (Earley \& Mosakowski, 2004). The cognitive dimension refers to the cultural knowledge of norms, behaviours, practices and conventions in different cultures, acquired from personal experience and education. It embodies knowledge of economic, social and legal systems of various cultures and sub-cultures, as well as knowledge of the cultural values (Rose, Ramalu, Uli, \& Kumar, 2010). The motivational dimension conceptualizes the capacity to direct attention and energy towards cultural differences; in other words, it is an auto-efficient form and intrinsic motivation in cross-cultural situations (Dyne et al., 2008). The behavioural dimension is one of the most visible dimensions of social interactions and refers to the capacity to exhibit, verbally and nonverbally, appropriate behaviours when interacting with people from different cultures (Van Dyne et al., 2008). This means that an individual will not be able to convince culturally diverse hosts just by showing them that he/she understands their culture; it will be necessary to prove through his/her attitudes that he/she is effectively integrated in their world (Earley \& Mosakowski, 2004).

Some studies have showed that individuals with higher cultural intelligence levels are more efficient in decision-taking in cross-cultural situations and have a higher probability to adapt themselves to situations characterized by cultural diversity (Bernardo \& Presbitero, 2018; Van Dyne, Ang, \& Nielsen, 2007). Furthermore, they also possess more effective cross-cultural leadership capacities (Deng \& Gibson, 2009). To develop the cognitive and behavioural dimensions of employees' cultural intelligence, organizations must promote cultural training, which will allow them to be more successful in international missions (Rehg, Gundlach, \& Grigorian, 2012).

Besides cultural intelligence, the multicultural personality dimensions are also considered as one of the most important antecedents in cultural adjustment, overtaking knowledge and technical competencies (Peltokorpi \& Froese, 2012). 


\section{Multicultural Personality (MPQ)}

The Van der Zee and Van Oudenhoven's (2000) multicultural personality model is anchored in the operational concept of multicultural efficacy. The multicultural efficacy, defined by White (1959) as the capacity to make things work, is related to the psychological well-being in a different cultural context (Van der Zee \& Van Oudenhoven, 2000) and with the success of an expatriate in the field of professional efficacy, personal adjustment and cultural interaction (Ponterotto, Rucksdeschel, Joseph, Tennenbaum, \& Bruno, 2011). The multicultural personality concept, developed by Van der Zee and Van Oudenhoven (2000), is divided into five dimensions: cultural empathy, openmindness, emotional stability, flexibility and social initiative. Cultural empathy, also called sensibility (e.g. Hawes \& Kealey, 1981), is the most referred dimension in cultural efficacy (e.g. Arthur \& Bennet, 1995; Ruben, 1976). It refers to the ability to show empathy with the feelings, thoughts and behaviours of the members of a culturally different group. The openmindness dimension refers to an open mind attitude without prejudice towards members, norms and different cultural values. The emotional stability dimension is related to the tendency for keeping calm in stressful situations versus the strong emotions showing tendency under big stress circumstances. The fourth dimension, flexibility, has been pointed by the authors (Arthur \& Bennet, 1995; Hanvey, 1976; Ruben \& Kealey, 1979) as an extremely important dimension, especially when the expectations about the host country do not match with the real situation. Flexibility elements, such as the capacity for learning with mistakes and leaning with new experiences, are crucial factors in multicultural efficacy (Spreitzer, McCall, \& Mahoney, 1997). Lastly, the social initiative dimension comprises an open attitude towards new cultures, a tendency to seek and explore new situations, facing them as challenges (Van der Zee \& Van Oudenhoven, 2001), and also the capacity to make and maintain contacts easily (Van der Zee \& Van Oudenhoven, 2000; Niejenhuis, Otten, \& Flache, 2018).

According to Ang, Van Dyne and Koh (2006), certain personality traits are associated with cultural intelligence capabilities. Personality traits are universal adaptive mechanisms, which include personality characteristics as the human ability to recognize and accept social hierarchies, the ability to play a serious and continuous work, the willingness to work, the ability to deal with stress, the strive for innovation, and the insight in solving problems (Kumar, Subramanian, \& Rose, 2008). Accordingly, in much the same way that cultural intelligence involves the ability to adapt to different cultural contexts, certain personality traits are expected to be related to cultural intelligence factors and to predict the divergent levels of cultural intelligence among individuals (Kumar et al., 2008). In their analysis of cultural intelligence and the Big Five, Ang and colleagues (2006) have found evidence of the relationship between personality traits and certain cultural intelligence dimensions: for example, conscientiousness and agreeableness are positively related to the metacognitive and behavioural dimensions, respectively; those who tend to be extroverted also show high levels in cognitive, motivational and behavioural dimensions; and those with higher openness to experience show positive results in all four dimensions of cultural intelligence (Ang et al., 2006). Despite being stable human characteristics, intelligence and personality may evolve in certain directions, i.e., individuals who tend to maintain contact with different cultures may increase their levels of cultural intelligence and multicultural personality. 


\section{CQ, MPQ and Intercultural contact}

The cultural intelligence and multicultural personality levels tend to vary according to the level of exposition to different cultures, the qualifications, and the frequency of contact with individuals from other cultures (Crowne, 2008). As well as being a challenge, entering a new culture allows individuals to contact with elements of different cultural groups, including members of the host society (co-nationals), immigrants/expatriates who settled there (host nationals) or even travellers (sojourners) (Geeraert, Demoulin, \& Demes, 2014). This social contact allows individuals to perceive cultural differences of different groups (Allport, 1954) and is one of the most effective ways to promote adjustment to an unfamiliar cultural environment. According to Crowne (2008), cultural exposure (which allows familiarity with norms, values, and beliefs of a particular culture) may be more superficial (e.g., through travel, reading, television programs, studying, or contacting someone from another culture) or deeper (e.g., through a process of expatriation and immigration, business, studying, and living in another country through humanitarian missions or even military experience). A wide-ranging cultural contact leads to a thorough understanding of the culture (Chen \& Isa, 2003), and individuals may learn how to select/apply appropriate tools and adapt them as needed (Johnson, Lenartowitcz, \& Apud, 2006). Furthermore, proximity with people from other nationalities (e.g., at work or with friends) may influence sociocultural adjustment as well intergroup identification (Geeraert et al., 2014), i.e., the closer and more frequent the contacts with members from other cultures, the better the multicultural adaptation. Frequent contact with individuals from different cultures may also reduce intergroup anxiety and increase the positive intercultural attitudes among major and minor groups (Ward \& Masgoret, 2006) and it is crucial for the cultural intelligence development (Crowne, 2008). In addition, contact is one way to reduce intergroup biases (e.g., Allport, 1954; Cao \& Lin, 2017; Dovidio, Love, Schellhaas, \& Hewstone, 2017). Once the process of categorization and intergroup hostility socially learned are the source of social prejudice, human beings tend to reject the unknown. In this sense, discrimination is a consequence of the lack of contact with other individuals or groups. By providing positive experiences, the contact between groups accentuates the perception of similarity between members of different groups. When individuals are open to the diversity of social groups, they tend not to show discriminatory attitudes towards those who are different, either based on race, gender or age (Lauring \& Selmer, 2013).

Even individuals working in their home country can be exposed to the multiculturalism, whether managing foreign workers, in international business, or communicating with their costumers, work colleagues, friends or family members. According to Rego and Cunha (2009) in Portugal, the Portuguese managers, while coordinating workers from different cultural origins, can deal with difficulties that could be reduced or overtaken whenever the managers show a high cultural intelligence level, as well as certain multicultural personality dimensions that will facilitate the interaction and adaptation to multiculturalism. Both are characteristics that develop in the cultural context (country) and small cultures (family, social categories, etc.) of individuals. This is the reason why the study by Sousa and colleagues (2019) showed that individuals who maintain intercultural contact in a professional context have higher levels of cultural intelligence, differences were also observed according to academic qualifications and gender. Therefore, it is important for 
organizations to replace their employees in order to be more efficient in a global context (Shaffer, Kraimer, Chen, \& Bolino, 2012). International missions usually allow the expatriates to increase their intercultural competencies, as they can acquire critical knowledge, global management capacities and cultural sensibility (Takeuchi \& Chen, 2013). However, if considering a failed expatriation process, organizations should take into account the level of cultural intelligence of its employees, as well as their cultural level and frequency of cultural exposure (travels, vacations, exchanges, work in other countries), since they can have high motivational levels of cultural intelligence and thus, be better prepared to deal with multiculturalism (Crowne, 2008). Knowing the characteristics of expatriates and of those who host them is fundamental for the organizations, in that certain aspects of cultural intelligence and multicultural personality may influence the international business success (Crowne, 2008).

Regarding social interactions, and according to Ward and Rana-Deuba (2000), the relationships between home country and the host country exercise a strong influence in the intercultural adjustment. For example, Davies and Aron (2016) concluded that friendship processes, whether interpersonal (e.g., affection, trust) or intergroup (e.g., spending time with family and friends of a friend from an outside group) lead to more favorable attitudes towards external groups, such as empathy (Korol, 2019). To Berry (1997), the environment and the attitudes of the home country population are important, since they can or cannot create a favourable context in which the acculturation processes and relations can be developed. If the dominant society insists on the assimilation of minorities or is intolerant to cultural diversity, the environment will give rise to misunderstandings and more contentious interactions. For many immigrants the process of integration is not always easy as it requires not only the adaptation of immigrants or minorities but also the adaptation of the host society (e.g., Moraes, Corte-Real, Dias, \& Fonseca, 2012; Sousa \& Gonçalves, 2015). This integration does not always develop positively. The immigrants and the cultures of each one constitutes social categories - the outgroups. Given the cognitive processes and the search for a positive identity (Social Identity Theory (Tajfel \& Turner, 1979); SelfCategorization Theory (Turner et al. 1987); Integrated Threat Theory (Stephan, Ybarra, \& Bachman, 1999), among others) prejudices are easily developed particularly in certain contexts, such as competition for resources, conflicts (e.g., Böhm, Rusch, \& Baron, 2018; Sherif \& Sherif, 1969). For example, multicultural policies such as those concerning the right to civic and political participation for immigrants (Fernandes-Jesus, Cicognagni, \& Menezes, 2014; Zobel \& Barbosa, 2011) may contribute to reducing intergroup bias and consequent conflicts, but can create situations of competition for resources and consequent gaps between groups (for a review, see Verkuyten \& Yogeeswaran, 2019).

At work, given that it is an already complex social context, the limitation of resources (awards, career progression, etc.) increases the fragility of organizational social harmony. Thus, the identification of the individual key competencies that facilitate multicultural adjustment is crucial not only for the organizations`cultural adjustment and their global success, but also for the social interactions that occur in today's societies.

Due to the relevance of this theme and the paucity of studies in this field (either with samples of Portuguese population or with these three variables together), our objective is to analyse the existing relation between the level of contact with individuals from other nationalities and their levels of cultural intelligence and multicultural personality. With that purpose, we conducted a quantitative study of univariate design (level of contact: none, work, friends/family, friends/work, expatriates). 


\section{Method}

\section{Sample}

The sample was collected through an online survey and is composed of 313 Portuguese participants (202 females and 111 males), 22 of which were expatriates. Age ranged from 18 to 72 , with a mean of 30.16 years $(\mathrm{SD}=13.26)$, and $67.7 \%$ of the participants were single; 167 participants had completed secondary school and 108 had a higher education degree.

\section{Procedure}

The survey used in this study was created in the Google Drive Platform and is composed of the Intelligence Cultural Scale, the Multicultural Personality Questionnaire, and specific questions regarding multicultural contact and socio-demographic characteristics. The survey also included information about the confidentially and anonymity for both the participants and the data. The survey web-link was redirected via email to the organizations, embassies, consulates and personal contacts whose collaboration was requested. Data collection lasted for two months, and after that time, all valid surveys were inserted in the SPSS program (Version 20) for statistical analysis.

\section{Measures}

The survey included the Intelligence Cultural Scale, the Multicultural Personality Questionnaire, questions about the contact with people from other nationalities, as well as biographic questions in order to characterize the sample (age, marital status, and schooling qualifications).

Cultural Intelligence Scale: Data about cultural intelligence was collected using the Cultural Intelligence Scale $(C Q S)$, originally developed by Van Dyne et al., (2008). It is composed by 20 items distributed in 4 dimensions: 4 items in the metacognitive dimension; 6 items in the cognitive dimension; 5 items in the motivational dimension and 5 items in the behavioural dimension. All items were measured using a Likert scale ranging from 1 "strongly disagree" to 7 "strongly agree". This scale was validated for the Portuguese population and shows psychometric properties similar to the original scale and a good adjustment to this population in the four cultural intelligence dimensions (Sousa et al., 2015). The internal consistency of the cultural intelligence scale shows a Cronbach alpha of 0.93. Concerning the internal consistency of factors, the first factor (metacognitive) presents an alpha of 0.89 , the second factor (cognitive) an alpha of 0.86 , the third (motivational) an alpha of 0.89 , and the fourth (behavioural) a Cronbach alpha of 0.89 .

Multicultural Personality Questionnaire: Data about multicultural personality was collected using the Multicultural Personality Questionnaire (MPQ), developed by Van der Zee and Van Oudenhoven (2000). The multicultural personality questionnaire scales are strongly related to Big-Five scales (Barrick \& Mount, 1991), but they are elaborated to cover more specifically the aspects that are determinant in multicultural success (Van Oudenhoven \& Van der Zee, 2002). This questionnaire comprises 91 items measuring 5 dimensions of intercultural competencies: cultural empathy (18), open-mindedness (18), 
emotional stability (20), social initiative (17), and flexibility (18). Respondents evaluated if each item is applicable to themselves based on a Likert Scale ranging from 1 "totally not applicable" to 5 " totally applicable". The face validity was supported by the translation-retranslation by four bilingual translators. The internal consistency of the MPQ is translated in a Cronbach alpha of 0.90 and the different factors show alphas of 0.84 (cultural empathy), 0.82 (open-mindedness), 0.82 (social initiative), 0.80 (emotional stability) and 0.67 in the flexibility dimension.

Intercultural contact: Similarly to the study of Crowne (2008), the intercultural contact variable was constructed taking into account the level of cultural exposure of individuals, i.e., participants indicated in what context they had contact with people from other nationalities, considering the following assumptions:

1. At work: (a) with colleagues, (b) with superiors, (c) with clients.

2. On a personal level: (a) with friends, (b) with family.

3. Being Expatriate.

4. Did not have any contact.

To address this question, the level of intercultural contact was operationalized in an escalating range of contact: (a) None (individuals who do not have any contact with people from other nationalities); (b) Work (individuals who maintain contact with people from other nationalities only on a professional level); (c) Friends/Family (individuals who maintain contact with people from other nationalities only on a personal level ); (d) Friends and Work (individuals who maintain contact with people from other nationalities, either personally or on a professional level ); (e) expatriates (individuals who are expatriates).

\section{Results}

The collected data was analysed with the SPSS statistical program (version 20.0) and the significant level was assumed at 0.05.

Through table 1, it is possible to observe that the metacognitive dimension $(\mathrm{M}=4.71)$ is the dimension that shows the highest mean and the cognitive dimension $(\mathrm{M}=3.59)$ the lowest mean. Expatriates show the highest mean in all four cultural intelligence dimensions, followed by those who maintain contact with people from other nationalities either in their work or in their personal life (friends and work). The ANOVA between-subjects analysis shows the effect of the degree of contact in all cultural intelligence dimensions $(p=.000)$. As can be seen, the effect is significant in all dimensions. 
Table 1. Means, standard deviations and ANOVA between-groups of CQ dimensions according to the level of intercultural contact

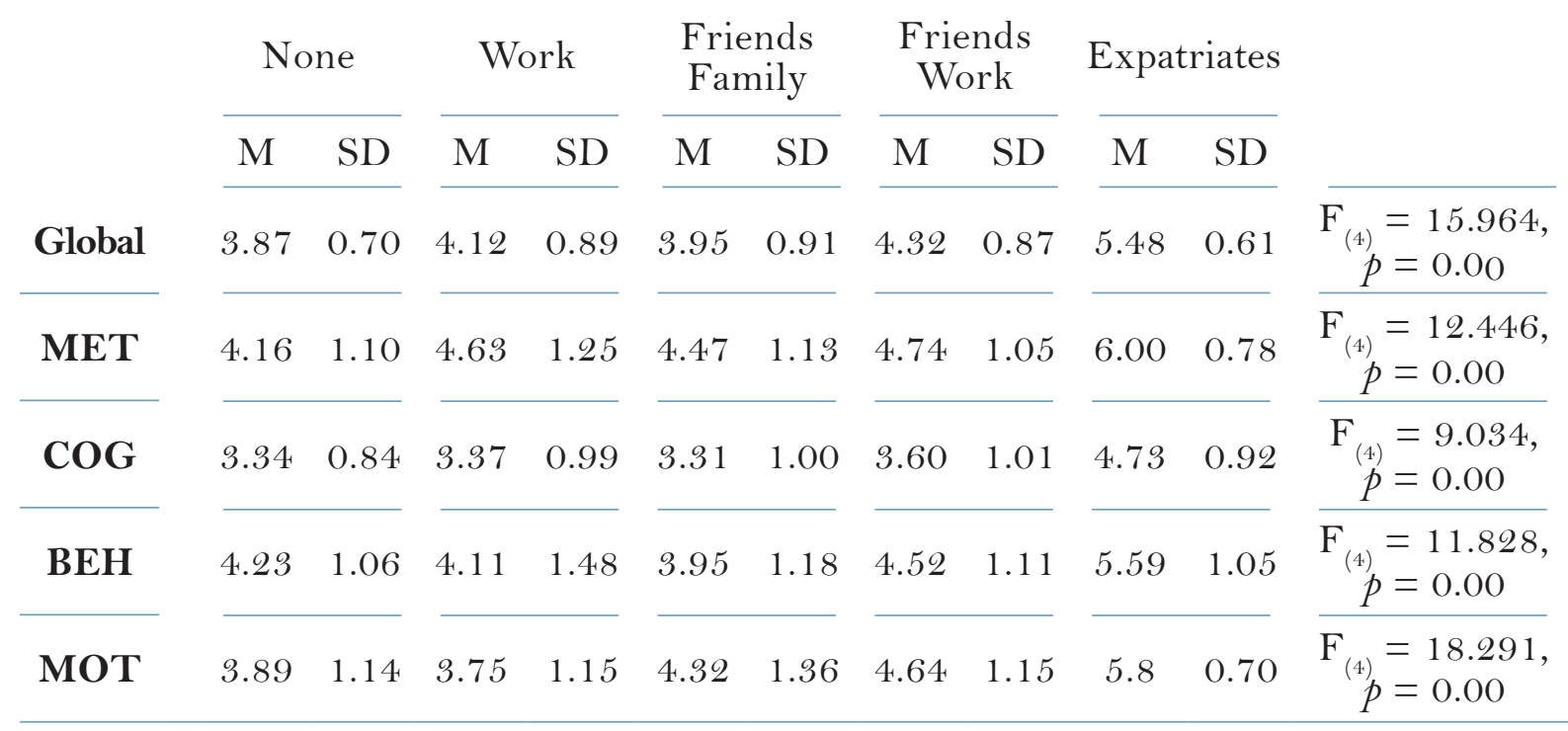

Tukey test results reveal that in all cultural intelligence dimensions, the highest level of contact, expatriates, is significantly higher than all the others $(p=.000)$. In metacognitive and motivational dimensions, Tukey test shows differences between the levels of contact none and friends and work $(\mathrm{p} \leq .05)$. Significant differences between the levels friends and friends and work in motivational $(\mathrm{p} \leq .002)$ and behavioural $(\mathrm{p} \leq .014)$ dimensions are also observed. In the cognitive dimension, the level of contact expatriates is significantly superior to all the others $(\mathrm{p}=.000)$.

Table 2. Means, standard deviations and ANOVA between-groups of MP dimensions according to the level of intercultural contact

\begin{tabular}{|c|c|c|c|c|c|c|c|c|c|c|c|}
\hline \multirow[b]{3}{*}{$\mathrm{CE}$} & \multicolumn{2}{|c|}{ None } & \multicolumn{2}{|c|}{ Work } & \multicolumn{2}{|c|}{$\begin{array}{l}\text { Friends } \\
\text { Family }\end{array}$} & \multicolumn{2}{|c|}{$\begin{array}{l}\text { Friends } \\
\text { Work }\end{array}$} & \multicolumn{2}{|c|}{ Expatriates } & \\
\hline & M & $\mathrm{SD}$ & M & SD & $\mathrm{M}$ & $\mathrm{SD}$ & $\mathrm{M}$ & $\mathrm{SD}$ & M & SD & \\
\hline & 3.63 & 0.44 & 3.52 & 0.59 & 3.67 & 0.43 & 3.70 & 0.44 & 3.71 & 0.37 & $\begin{aligned} \mathrm{F}_{(4)} & =1.015, \\
p & =0.40\end{aligned}$ \\
\hline OM & 3.20 & 0.42 & 3.18 & 0.50 & 3.36 & 0.46 & 3.48 & 0.43 & 3.71 & 0.38 & $\begin{aligned} \mathrm{F}_{(4)} & =1.437, \\
p & =0.00\end{aligned}$ \\
\hline SI & 3.14 & 0.39 & 3.33 & 0.57 & 3.32 & 0.48 & 3.46 & 0.42 & 3.84 & 0.32 & $\begin{aligned} \mathrm{F}_{(4)} & =1.864, \\
p & =0.00\end{aligned}$ \\
\hline ES & 2.94 & 0.40 & 3.11 & 0.46 & 2.98 & 0.45 & 3.03 & 0.42 & 3.39 & 0.29 & $\begin{aligned} \mathrm{F}_{(4)} & =0.862, \\
p & =0.00\end{aligned}$ \\
\hline FLE & 3.08 & 0.37 & 3.18 & 0.25 & 3.29 & 0.33 & 3.31 & 0.36 & 3.47 & 0.38 & $\begin{aligned} \mathrm{F}_{(4)} & =0.653, \\
p & =0.00\end{aligned}$ \\
\hline
\end{tabular}

Cultural empathy $(M=3.67)$, open-mindedness $(M=3.42)$ and social initiative $(M=$ 3.42) dimensions are those with the highest means, followed by flexibility $(M=3.28)$ and emotional stability $(\mathrm{M}=3.42)$ (Table 2$)$. 
Similarly to the results obtained for cultural intelligence, the expatriates and the level of contact friends and work show the highest multicultural personality means in all dimensions. Through table 2 , it is possible to observe that ANOVA between-subject analysis shows the effect of the level of contact on the several multicultural personality dimensions $(p \leq .001)$, except for the cultural empathy dimension $(p \leq .400)$.

The Tukey test results reveal that, in all multicultural personality dimensions, the highest level of contact, expatriates, is significantly superior to all the others ( $\mathrm{p} \leq$ .05), except for the cultural empathy dimension, where, independently of the contact, no significant difference was observed. In the open-mindedness dimension there are significant differences between the levels of contact none and friends and work, and between the levels work and friends and work $(\mathrm{p} \leq .009)$. In the social initiative dimension significant differences between the levels none and friends and work ( $\mathrm{p} \leq .001)$ were found. In the flexibility dimension significant differences between the levels none and friends and work $(\mathrm{p} \leq .005)$ and between none and friends $(\mathrm{p} \leq .044)$ were observed. In the emotional stability dimension, the level of contact expatriates is significantly superior to all the others $(p=.000)$.

\section{Discussion}

The main purpose of this study was to analyse the degree to which cultural intelligence and multicultural personality are influenced by the level of contact with people from different nationalities. Our results show that expatriates have higher cultural intelligence and multicultural personality levels. Regarding cultural intelligence, subjects who have greater contact with individuals from other nationalities (with friends or at work) present higher means in all cultural intelligence dimensions, in comparison with the remaining contact levels, except for expatriates. In reference to multicultural personality, the contact level friends show superior means in all dimensions, except for emotional stability. This dimension, closely related to the ability for keeping calm in stress situations, is a dimension that might not be directly influenced by the contact level with different cultures. Cultural empathy is the dimension with the highest means, independently of contact level. This dimension is associated with the ability to demonstrate sympathy with the sentiments, thoughts and behaviours of individuals from other cultures. The Portuguese society denotes to be tolerant to cultural differences.

When selecting expatriates, organizations should take into consideration the individuals' cultural experience and their level of contact with other cultures (at work, on holidays, or in interchange situations). The frequent contact with people is crucial to the development of cultural intelligence and multicultural personality. It increases positive intercultural attitudes and facilitates interaction, intercultural adaptation, and adjustment. Being culturally intelligent or possessing certain multicultural personality qualities is essential not only to the global human resource management success and to the international organizations' efficacy, but also for improving cross cultural interactions in social life. 


\section{Limitations}

One of the limitations in this study is the small number of expatriates in our sample when compared to non-expatriates. Furthermore, despite the advantages of reduced time and costs associated with online questionnaires, it is not possible to control the response time and the spontaneity of respondents. The length of the questionnaire may also act as a disincentive to complete it accurately and in its entirety. Another limitation is the need to develop the operationalization of the variable measuring contact, given that it is not possible to assess the frequency of contact between the subjects.

\section{Practical implications and future research}

Understanding the nature and impact of cultural intelligence and multicultural personality on the performance of individuals, teams, and organizations in multicultural backgrounds will be an asset to global organizations and for multicultural societies. The development of an effective international communication will be a key tool for organizations, as it allows to define integration strategies for both expatriates and immigrants. It further allows the definition of strategies for conflict and negotiation management in contexts characterized by diversity and multiculturalism. Living in a world increasingly diversified is not only a challenge but also an opportunity to learn more about our own culture and identity, as well as to be aware of our similarities and differences with others with whom we communicate (Kim, 2012). By becoming aware of the cultural differences, values, habits and communication rules of each society and culture, individuals and organizations will be more prepared for international human resource management and for the promotion of peace processes and social justice.

This study also contributes to defining measures of predictive validity regarding the selection of expatriates and intervention strategies for expatriate training. Therefore, research-action studies may be developed by using assessment centres extended to participants of the host culture (not only to other employees in similar circumstances), in order to assess the extent to which the contact with people from other nationalities contributes to the effectiveness of integration strategies. A set of longitudinal studies supervising cultural competence development may also be conducted.

Similarly, it would be interesting to analyse to what extent the level of cultural intelligence and multicultural personality vary according to cultural values (Hofstede, 2001), i.e., the cultural background of the foreigners (individualist or collectivist) with whom the contact is maintained. Still related to cultural values, it would be pertinent to extend this study to countries such as Brazil, marked by a history of colonization, and where intercultural contact is more frequent. This study does not address contact based on the different social categories of immigrants and the social experience of this contact. Existing prejudice about certain national categories (e.g., Chinese, Russian, Swedish, Brazilian) and language difficulties can cause negative contact experiences and therefore negatively affect cultural intelligence and multicultural personality. Further investigations may deepen the differences in intercultural contact regarding immigrant type (e.g., illegal immigrants vs asylum seekers) (e.g., Ghosn et al., 2019). This study could be extended to populations of 
immigrants and emigrants, which, contrary to expatriates, have no organizational support, preparation, or intercultural training. However, culture shock is inevitable and the development of abilities such as cultural intelligence and multicultural personality facilitate their adjustment and integration into a new culture. Future studies may further assess whether cultural intelligence and multicultural personality mediate the negative relationship between contact and intergroup prejudice, as postulated by Allport.

\section{Conclusions}

Cultural intelligence and multicultural personality are individual characteristics that are fundamental to the success of intercultural relations. They facilitate adjustment and interaction with individuals from other cultures and allow for rapid adaptation to situations of cultural diversity. In addition, multicultural competencies go beyond improving the social interactions associated with cultural diversity, they are also important in conflict management, contributing to an improved relationship between people and groups (e.g., Gonçalves, Reis, Sousa, Santos, \& Orgambídez-Ramos, 2015; Gonçalves et al., 2016).

Maintaining contact with different cultures contributes significantly to an increase in the overall levels of cultural intelligence and multicultural personality. Similarly, it contributes to an increased awareness of cultural differences and similarities, reducing the risk of conflict and increasing the efficiency of adjustment and acculturation processes.

In order to achieve effectiveness and organizational success in an increasingly global context, organizations and individuals are required to develop individual skills to operate with diverse cultures. Being culturally intelligent, having a multicultural personality or having frequent contact with other cultures is, undoubtedly, an asset to achieve such effectiveness. Multicultural groups are inevitable in a globalized world (Rego \& Cunha, 2009). An in-depth knowledge of this reality will help organizations to define strategies to manage global human resource management and social dynamics, based on the identification of core competencies for multicultural adaptation, well-being and employees' quality of life.

\section{References}

Adler, P. S. (2002). International dimensions of organizational behaviour. Cincinnati, OH: SouthWestern.

Ali, A., Van der Zee, K. I., \& Sanders, G. (2003). Determinants of intercultural adjustment among expatriate spouses. International Journal of Intercultural Relations, 27(5), 563-580.

Allport, G. W. (1954). The nature of prejudice. Reading, MA: Addison-Wesley.

Ang, S., Van Dyne, L. V., \& Koh, C. (2006). Personality correlates of the four-factor model of cultural intelligence. Group and Organization Management, 31(1), 100-123.

Arthur, W. \& Bennet, W. (1995). The international assign: The relative importance of factors perceived to contribute to success. Personnel Psychology, 48, 99-114.

Barrick, M. R., \& Mount, M. K. (1991). The Big Five Personality Dimensions and Job Performance. Personnel Psychology, 41, 1-26. 
Bernardo, A. \& Presbitero, A. (2018). Cognitive flexibility and cultural intelligence: Exploring the cognitive aspects of effective functioning in culturally diverse contexts. International Journal of Intercultural Relations, 66, 12-21.

Berry, J. W. (1997). Immigration, acculturation and adaptation. Applied Psychology: An International Review, 46(1), 5-68.

Böhm, R., Rusch, H., \& Baron, J. (2018). The Psychology of Intergroup Conflict: A Review of Theories and Measures. Journal of Economic Behavior \& Organization. Retrieved https://www.researchgate.net/publication/322666126 The Psychology of Intergroup Conflict A Review of Theories and Measures

Cao, B. \& Lin, W-Y (2017). Revisiting the contact hypothesis: Effects of different modes of computer-mediated communication on intergroup relationships. International Journal of Intercultural Relations, 58, 23-30

Chen, L. \& Isa, M. (2003). Intercultural communication and cultural learning: The experience of Japanese visiting students in the U.S. Howard Journal of Communication, 14(2), 75-96.

Crowne, K. (2008). What leads to cultural intelligence? Business Horizons, 51(5), 391-399.

Davies, K. \& Aron, A. (2016). Friendship Development and Intergroup Attitudes: The Role of Interpersonal and Intergroup Friendship Processes. Journal of Social Issues, $72(3), 488-510$.

Deng, L. \& Gibson, P. (2009). Mapping and modelling the capacities that underlie effective cross-cultural leadership. An interpretative study with practical outcomes. Cross Cultural Management: An international journal, 16(4), 347-366.

Dovidio, J., Love, A., Schellhaas, F., \& Hewstone, M. (2017). Reducing intergroup bias through intergroup contact: Twenty years of progress and future directions. Group Pro-

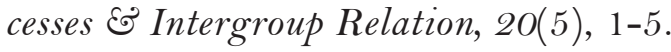

Earley, P. C. \& Ang, S. (2003). Cultural Intelligence: Individual Interactions across Cultures. Palo Alto, CA: Stanford University Press.

Earley, P. C. \& Mosakowski, E. (2004). Cultural intelligence. Harvard Business Review, 82(10), 139-153.

Fang, F., Schei, V., \& Selart, M. (2018). Hype or hope? A new look at the research on cultural intelligence. International Journal of Intercultural Relations, 66, 148-171.

Fernandes-Jesus, M., Cicognagni, E., \& Menezes, I. (2014). Participação cívica e política: jovens imigrantes brasileiros/as em Portugal. Psicologia e Sociedade, 26(3), 572-582.

Geeraert, N., Demoulin, S., \& Demes, K. (2014). Choose your (international) contacts wisely: A multilevel analysis on the impact of intergroup contact while living abroad. International Journal of Intercultural Relations, 38(1), 86-96.

Ghosn, F., Braithwaite, A., \& Chu, T. (2019). Violence, displacement, contact, and attitudes toward hosting refugees. Journal of Peace Research, 56(1), 118-133.

Gonçalves, G., Reis, M., Sousa, C., Santos, J., \& Orgambidez-Ramos, A. (2015). The effect of multicultural experience in conflicts management styles: mediation of cultural intelligence and self-monitoring. Journal of Spatial and Organizational Dynamics - Multiculturality in organizational and social space: Nerw challenges, 3(1), 4-2 1. 
Gonçalves, G., Reis, M., Sousa, C., Santos, J., Orgambídez-Ramos, A., \& Scott, P. (2016). Cultural Intelligence and conflict management styles. International Journal of Organizational Analysis, 24(4), 725-742.

Hanvey, R. G. (1976). Cross-cultural awareness. In E. C. Smith \& L. F. Luce (Eds.), Towards internationalism: Readings in cross-cultural communication (pp. 44-56). Rowley, MA: Newbury House Publishers.

Hawes, F. \& Kealy, D. (1981). An empirical study of Canadian technical assistance: Adaptation and effectiveness on overseas assignment. International Journal of Intercultural Relations, 5(3), 239-258.

Hofstede, G. (2001). Culture's consequences: Comparing values, behaviors, institutions and organizations across nations (2a ed.). London: Sage.

Johnson, J. P., Lenartowicz, T., \& Apud, S., (2006). Cross-cultural competence in international business: Toward a definition and a model. Journal of International Business Studies, 37(4). 525-543.

Kim, Min-Sun (2012). World peace through intercultural research: From a research culture of war to a research culture of peace. International Journal of Intercultural Relations, 36(1), 3-13.

Korol, L. (2019) Does multicultural personality moderate the relationship between crossgroup friendship and allophilia? The Journal of Social Psychology, 159(6), 649-663.

Kumar, N., Rose, R., \& Subramaniam, S. (2008). The effects of Personality and Cultural Intelligence on International Assignment Effectiveness: A Review. Journal of Social Sciences 4(4), 320-328.

Lauring, J. \& Selmer, J. (2013). Diversity attitudes and group knowledge processing in multicultural organizations. European Management Journal, 31(2), 124-136.

Lorenz, M., Ramsey, J., \& Richey, G. (2018). Expatriates' international opportunity recognition and innovativeness: The role of metacognitive and cognitive cultural intelligence. Journal of World Business, 53(2), 222-236.

Malheiros, J. (2011). Promoção da interculturalidade e da Integração de Proximidade - Manual para técnicos. Lisboa: ACIDI.

Mol, S. T., Van Oudenhoven, J. P., \& Van der Zee, K. I. (2001). Validation of the Multicultural Personality Questionnaire among an internationally oriented student population in Taiwan. In F. Salili \& R. Hoosain (Eds.), Research in multicultural education and international perspectives (pp. 167-186). Greenwich, CT: Information Age Publishing.

Moraes, M., Corte-Real, N., Dias, C., \& Fonseca, A. M. (2012). Um olhar sobre a prática desportiva, bem-estar subjetivo e integração social de imigrantes... em Portugal e no mundo. Psicologia E' Sociedade, 24(1), 208-216.

Niejenhuis, C., Otten, S., \& Flache, A. (2018). Sojourners' second language learning and integration. The moderating effect of multicultural personality traits. International Journal of Intercultural Relations, 63, 68-79.

Peltokorpi, V. \& Froese, F. J. (2012). The impact of expatriate personality traits on crosscultural adjustment: A study with expatriates in Japan. International Business Review, 21(4), 734-746.

Pettigrew, T. F. \& Tropp, L. R. (2006). A meta-analytic test of intergroup contact theory. Journal of Personality and Social Psychology, 90(5), 751-783. 
Ponterotto, J., Rucksdeschel, D., Joseph, A., Tennenbaum, E., \& Bruno, A. (2011). Multicultural personality dispositions and trait emotional intelligence: an exploratory study. The Journal of Social Psychology, 151(5), 556-576.

Rego, A. \& Cunha, M. P. (2009). Manual de Gestão Transcultural de Recursos Humanos, Lisboa: Editora RH.

Rehg, M., Gundlach, M., \& Grigorian, R. (2012). Examining the influence of cross-cultural training on cultural intelligence and specific self-efficacy. Cross Cultural Management: An international Journal, 19(2), 215-232.

Rockstuhl, T. \& Van Dyne, L. (2019). A bi-factor theory of the four-factor model of cultural intelligence: Meta-analysis and theoretical extensions. Organizational Behavior and Human Decision Processes, 148, 124-144. Recuperado de https://culturalq.com/wpcontent/uploads/2019/03/OBHDP-2018-Rockstuhl-Van-Dyne.pdf

Rose, R., Ramalu, S., Uli, J., \& Kumar, N. (2010). Expatriate performance in international assignment: The role of cultural intelligence as dynamic intercultural ompetency. International Journal of Business and Management, 5(8), 76-85.

Ruben, B. (1976). Assessing communication competence for intercultural adaptation. Group and Organizations Studies, 1(3), 334-354.

Ruben, B. \& Kealey, D. J. (1979). Behavioral assessment of communication competency and the prediction of cross-cultural adaptation. International Journal of Intercultural Relations, 3(1), 15-17.

Shaffer, M., Kraimer, M., Chen, Y., \& Bolino, M. (2012). Choices, challenges, and career consequences of global work experiences: A review and future agenda. Journal of Management, 38(4), 1282-1327.

Sherif, M. \& Sherif, C. (1969). Social psychology (3a ed.). New York: Harper and Row.

Sousa, C. \& Gonçalves, G. (2015). Imigrantes e sociedade de acolhimento - Percepções e realidades: O caso de Portugal. Psicologia E Sociedade, 27(3), 548-557.

Sousa, C., Gonçalves, G., \& Santos, J. (2019). Intercultural Contact as a Predictor of Cultural Intelligence. Universitas Psychologica, 18(2), 1-12.

Sousa, C., Gonçalves, G., Reis, M., \& Santos, J. (2015). Evidências Métricas da Escala de Inteligência Cultural numa amostra Portuguesa. Psicologia: Reflexão e Crítica, 28(2), 232-241.

Spreitzer, G. M., McCall, M. W., \& Mahoney, J. D. (1997). Early identification of international executive potential. Journal of Applied Psychology, 82(1), 6-29.

Stephan, W. G., Ybarra, O., \& Bachman, G. (1999). Prejudice toward immigrants. Journal of Applied Social Psychology, 29(11), $2221-2237$.

Tajfel, H. \& Turner, J. C. (1979). An Integrative Theory of Intergroup Conflict. In W. G. Austin \& S. Worchel (Eds.), The Social Psychology of Intergroup Relations (pp. 33-47). Monterey, CA: Brooks/Cole.

Takeuchi, R. \& Chen, J. (2013). The impact of international experiences for expatriates'crosscutural adjustment: A theoretical review and a critique. Organizational Psychology Review, 3(3), 248-290.

Turner, J. C. et al. (1987). Rediscovering the Social Group: A Self-Categorization Theory. Oxford \& New York: Blackwell. 
Van der Zee, K. I., \& Van Oudenhoven, J. P. (2000). The Multicultural Personality Questionnaire: A multidimensional instrument of multicultural effectiveness. European Journal of Personality, 14(4), 291-309.

Van der Zee, K. I. \& Van Oudenhoven, J. P. (2001). The Multicultural Personality Questionnaire: Reliability and Validity of Self and Other Ratings of Multicultural Effectiveness. Journal of Research in Personality, 35(3), 278-288.

Van der Zee, IK. I., Van Oudenhoven, J. P., \& Grijs, E. D. (2004). Personality, threat and cognitive and emotional reactions to stressful intercultural situations. Journal of Personality, 72(2), 1069-1096.

Van Dyne, L., Ang, S., \& Koh, C. (2008). Development and validation of the CQS. In S. Ang, \& L. Dyne (Org.), Handbook of Cultural Intelligence. Theory, measurement and applications, (pp. 16-38). New York: Sharpe.

Van Dyne, L., Ang, S., \& Livermore, D. (2010). Cultural Intelligence: A pathway for leading in a rapidly globalizing world. In K. Hannum, B. B. McFeeters, \& L. Booysen (Org.), Leading across differences (pp.131-138). San Francisco, CA: Pfeiffer.

Van Dyne, L., Ang, S., \& Nielsen, T.M. (2007). Cultural intelligence. In S. Clegg \& J. Bailey (Orgs.), International Encyclopedia of Organization Studies (Vol.1, pp. 345-350). Thousand Oaks, CA: Sage.

Van Oudenhoven, J. P. \& Van der Zee, K. I. (2002). Predicting multicultural effectiveness of international students: The Multicultural Personality Questionnaire. International Journal of Intercultural Relations, 26(6), 679-694.

Verkuyten, M. \& Yogeeswaran, K. (2019). Cultural diversity and its implications for intergroup relations. Current Opinion in Psychology, 32, 1-5.

Ward, C \& Rana-Deuba, A. (2000). Home and host culture influences sojourner adjustment. International Journal of Intercultural Relations, 24(3), 291-306.

Ward, C. \& Masgoret, A. (2006). An integrative model of attitudes toward immigrants. International Journal of Intercultural Relations, 30(6), 671-682.

White, R. W. (1959). Motivation considered: the concept of competence. Psychological Review, 66(5), 297-333.

William, C. \& Johnson, L. (2011). Why can't be friends? Multicultural attitudes and friendships with international students. International Journal of Intercultural Relations, $35(1), 41-48$.

Zobel, C. \& Barbosa, C. (2011). O acesso dos imigrantes ao voto e aos cargos eleitorais nas autarquias portuguesas. Revista Migrações, 8, 57-76. 


\section{CÁTIA SOUSA}

https://orcid.org/0000-0001-9905-8138

Graduation in Human Resource Management. Master in Work Sciences and Labour Relations. PhD in Psychology.

Guest Assistant Professor in the Department of Psychology and Educational Sciences, University of Algarve.

Member of the CIEO - Research Centre for Spatial and Organizational Dynamics (University of Algarve)

Address: Universidade do Algarve, Campus de Gambelas, 8005-139 Faro, Portugal.

E-mail: cavsousa@ualg.pt

\section{GABRIELA GONÇALVES}

https://orcid.org/0000-0002-9480-3239

Assistant Professor (PhD), University of Algarve (Portugal).

E-mail: ggoncalves@ualg.pt

\section{JOANA SANTOS}

https://orcid.org/0000-0003-2612-8056

Assistant Professor (PhD), University of Algarve (Portugal).

E-mail: jcsantos@ualg.pt

\section{ALEJANDRO ORGAMBÍDEZ-RAMOS \\ https://orcid.org/0000-0003-3785-4336}

Adjunct Professor (PhD), University of Malaga (Spain).

E-mail: aoramos@ualg.pt

\begin{tabular}{|c|c|}
\hline History & $\begin{array}{l}\text { Submission date: 7/20/2016 } \\
\text { Revision date: 4/30/2018 } \\
\text { Acceptance date: 10/29/2019 }\end{array}$ \\
\hline $\begin{array}{l}\text { Authors' } \\
\text { Contributions }\end{array}$ & $\begin{array}{l}\text { Conception: C.S.; G.G. } \\
\text { Data collection: C.S.; G.G. } \\
\text { Data Analysis: J.S.; A.O.R.; C.S. } \\
\text { Writing of the manuscript: C.S.; G.G. } \\
\text { Final approval of the manuscript: G.G.; J.S. }\end{array}$ \\
\hline $\begin{array}{l}\text { Funding/ } \\
\text { Financial Support }\end{array}$ & $\begin{array}{l}\text { This paper is financed by National Funds provided by FCT- } \\
\text { Foundation for Science and Technology through project } \\
\text { UID/SOC/04020/2013 }\end{array}$ \\
\hline $\begin{array}{l}\text { Image Usage } \\
\text { Consent }\end{array}$ & Not applicable. \\
\hline
\end{tabular}

